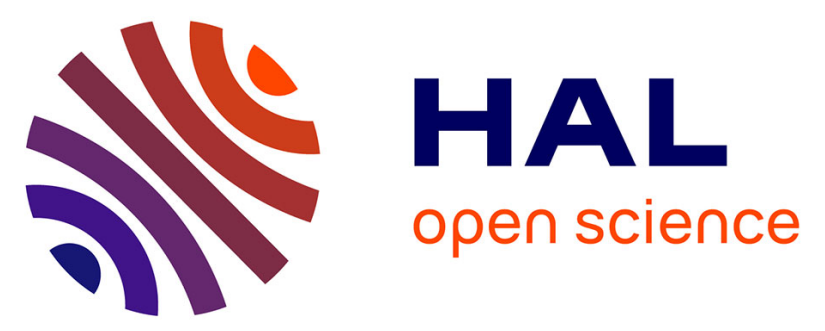

\title{
Synthesis of novel 3-(quinazol-2-yl)-quinolines via SNAr and aluminum chloride-induced (hetero) arylation reactions and biological evaluation as proteasome inhibitors
}

I. Boualia, A. Debache, R. Boulcina, Thierry Roisnel, F. Berrée, J. Vidal, B. Carboni

\section{To cite this version:}

I. Boualia, A. Debache, R. Boulcina, Thierry Roisnel, F. Berrée, et al.. Synthesis of novel 3(quinazol-2-yl)-quinolines via SNAr and aluminum chloride-induced (hetero) arylation reactions and biological evaluation as proteasome inhibitors. Tetrahedron Letters, 2020, 61 (17), pp.151805. 10.1016/j.tetlet.2020.151805 . hal-02569954

\section{HAL Id: hal-02569954}

\section{https://hal-univ-rennes1.archives-ouvertes.fr/hal-02569954}

Submitted on 12 May 2020

HAL is a multi-disciplinary open access archive for the deposit and dissemination of scientific research documents, whether they are published or not. The documents may come from teaching and research institutions in France or abroad, or from public or private research centers.
L'archive ouverte pluridisciplinaire HAL, est destinée au dépôt et à la diffusion de documents scientifiques de niveau recherche, publiés ou non, émanant des établissements d'enseignement et de recherche français ou étrangers, des laboratoires publics ou privés. 


\section{Graphical Abstract}

Synthesis of novel 3-(quinazol-2-yl)-quinolines via $S_{N} A r$ and aluminum chloride-induced (hetero) arylation reactions and biological evaluation as proteasome inhibitors

Imen Boualia, Abdelmadjid Debache, Raouf Boulcina, ${ }^{*}$ Thierry Roisnel, Fabienne Berrée, Joelle Vidal, ${ }^{*}$ and Bertrand Carboni<smiles>[R]c1ccc2nc(Cl)c(-c3nc(Cl)c4ccccc4n3)cc2c1</smiles>

$\mathrm{R}=\mathrm{H}, \mathrm{Me}, \mathrm{OMe}$

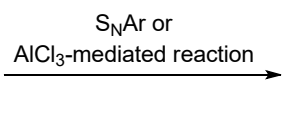$$
\mathrm{R}^{2}=\mathrm{Cl} \text {, OAr, NHTol, HetAr, morpholino }
$$

26 examples

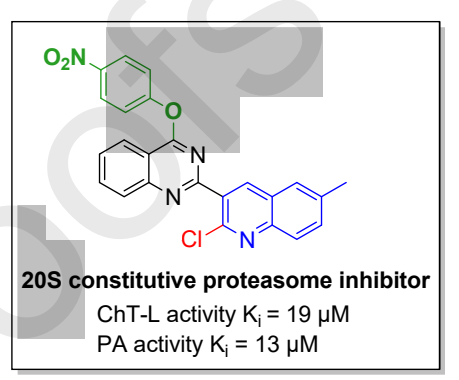




\section{Synthesis of novel 3-(quinazol-2-yl)-quinolines via $\mathrm{S}_{\mathrm{N}} \mathrm{Ar}$ and aluminum chloride- induced (hetero) arylation reactions and biological evaluation as proteasome inhibitors}

Imen Boualia, ${ }^{\mathrm{a}, \mathrm{b}}$ Abdelmadjid Debache, ${ }^{\mathrm{a}}$ Raouf Boulcina, ${ }^{\mathrm{a}, \mathrm{c} *}$ Thierry Roisnel, ${ }^{\mathrm{b}}$ Fabienne Berrée, ${ }^{\mathrm{b}}$ Joëlle Vidal, $^{\text {,* }}$ and Bertrand Carboni ${ }^{\mathrm{b}}$

${ }^{a}$ Laboratoire de Synthèse des Molécules d'Intérêts Biologiques, Université des Frères Mentouri-Constantine, 25000 Constantine, Algérie.

${ }^{b}$ Univ Rennes, CNRS, ISCR (Institut des Sciences Chimiques de Rennes) - UMR 6226, F-35000 Rennes, France. E-mail: joelle.vidal@univ-rennes1.fr

${ }^{c}$ Département des Sciences et Techniques, Faculté de Technologie, Université Mostefa Benboulaïd-Batna 2, 05000 Batna, Algérie. E-mail: r.boulcina@univ-

batna2.dz

\section{ABSTRACT}

A new series of 3-(quinazol-2-yl)-quinolines was synthesized by $\mathrm{S}_{\mathrm{N}} \mathrm{Ar}$ reaction from easily prepared 4-chloro-2-(2-chloroquinolin-3-yl)quinazolines and a range of phenols and thiophenol as nucleophiles. The $\mathrm{AlCl}_{3}$-mediated $\mathrm{C}-\mathrm{C}$ bond formation was also successfully exploited to introduce aryl and hereroaryl substituents on one or both heterocyclic units. These procedures afford efficient syntheses of polysubstituted 3-(quinazol-2-yl)-quinolines in few steps and high yields. Some of these polysubstituted 3-(quinazol-2-yl)-quinolines inhibit the human 20S proteasome.

The quinoline core is found in many natural products and has a privileged role in drug discovery. ${ }^{1}$ For example, camptothecin, topotecan, belotecan or cabozatinib, that inhibit topoisomerase or tyrosine kinases, are currently approved as anticancer treatment. Quinoline scaffold has also been used in the search for inhibitors of other important cancer targets, such as tubulin polymerization, DNA repair and proteasome. ${ }^{1-2}$ In the field of proteasome, quinolines are also widely represented as depicted in Figure $1 .^{3}$ Such derivatives could overcome some problems encountered with the pharmacodynamic and pharmacokinetic profiles of the proteasome inhibitors currently approved in cancer therapy (bortezomib, carfilzomib and ixazomib), usually attributed to their peptide structure and the presence of an electrophilic warhead. ${ }^{2 b}$ In the wide family of quinolines derivatives, hybrids which combines this scaffold with a quinazoline moiety, another important heterocycle possessing significant biological activities, ${ }^{4}$ are poorly exemplified (Fig. 2).
A.<smiles>O=C(NCCc1nccs1)c1cnc2c(Sc3cccc4cc(C(=O)NCCc5nccs5)cnc34)cccc2c1</smiles>

capzimin $^{3 a}$
B.<smiles>CCCCNC(=O)C1CC2CCCCC2CN1CC(O)C(Cc1ccccc1)NC(=O)C(CC(N)=O)NC(=O)c1ccc2ccccc2n1</smiles>

saquinavir $^{3 b}$<smiles>Oc1c(I)cc(Cl)c2cccnc12</smiles>

clioquinol $^{3 c, 3 d}$<smiles>[R]OS(=O)(=O)c1ccc(NC(=O)c2ccnc3ccccc23)cc1</smiles>
$1^{3 h}$<smiles>CCC(C)Nc1ccnc2cc(Cl)ccc12</smiles>

chloroquine $^{3 e}$<smiles>Nc1ccc(O)c2ncccc12</smiles><smiles>O=[N+]([O-])c1ccc(S(=O)(=O)N2CCNCC2)c([N+](=O)[O-])c1</smiles>

VR-23 ${ }^{39}$<smiles>Clc1ccc2cccnc2c1</smiles><smiles>CNC(/N=C\SCc1ccc2ccccc2n1)NOS(=O)(=O)c1ccccc1</smiles>

${ }^{3 i}$<smiles>Cc1nc2ccc(N(C)C)cc2cc1C1CCCCC1</smiles>

III ${ }^{3 \mathrm{j}}$

Fig.1 Structures of proteasome inhibitors bearing a quinoline scaffold (A. inhibitor of the proteasome 19S particle; B. inhibitors of the proteasome 20S core particle). 
They were mostly synthesized by palladium-catalyzed carbonylation of 2-aminobenzylamine and 2-bromoquinoline, ${ }^{5}$ Suzuki coupling of the chloroquinazolinone with 2-quinolyl boronic acid, ${ }^{6}$ or DMAP-catalyzed one-pot three-component reaction from 2-formylquinolines, 2-aminobenzophenones and ammonium acetate. ${ }^{7}$

In continuation of our research program centered on the design and synthesis of potentially bioactive molecules ${ }^{8}$ and, as part of our studies on non-peptide and non-covalent $20 \mathrm{~S}$ proteasome inhibitors, ${ }^{3 \mathrm{~h}, 9}$ we here focus on the preparation of a series of novel hybrid 3-(quinazol-2yl)-quinolines 6-15 via $\mathrm{S}_{\mathrm{N}} \mathrm{Ar}$ and $\mathrm{AlCl}_{3}$ induced (hetero) arylation reactions of 5 and their $20 \mathrm{~S}$ proteasome inhibition evaluation (Fig. 2).<smiles>[R]c1ccc2nc(-c3cc4cc([R])ccc4nc3-c3nc(Cl)c4ccccc4n3)c(Cl)cc2c1</smiles>

Fig.2 Targeted 3-(quinazol-2yl)-quinolines 6-15 and their precursor 5 .

To access to our common building blocks $\mathbf{5}$, intermediates $\mathbf{3 a -}$ c were first prepared in high yields by using procedures previously reported in our laboratory. ${ }^{8 c}$ Couplings of the 2aminobenzamide $\mathbf{1}$ with appropriate quinoline-3-carboxaldehydes 2 were carried out in the presence of $\mathrm{K}_{2} \mathrm{CO}_{3}$ in DMF at $80{ }^{\circ} \mathrm{C}$ (Scheme 1). On treatment with iodine in DMF at $80{ }^{\circ} \mathrm{C}, 3 \mathbf{3 a - c}$ exclusively gave the desired oxidized product 4 a-c in $76-86 \%$ yields. Chlorination was then readily achieved with phosphorus oxychloride giving $\mathbf{5 a - c}$ in $70-78 \%$ yields.

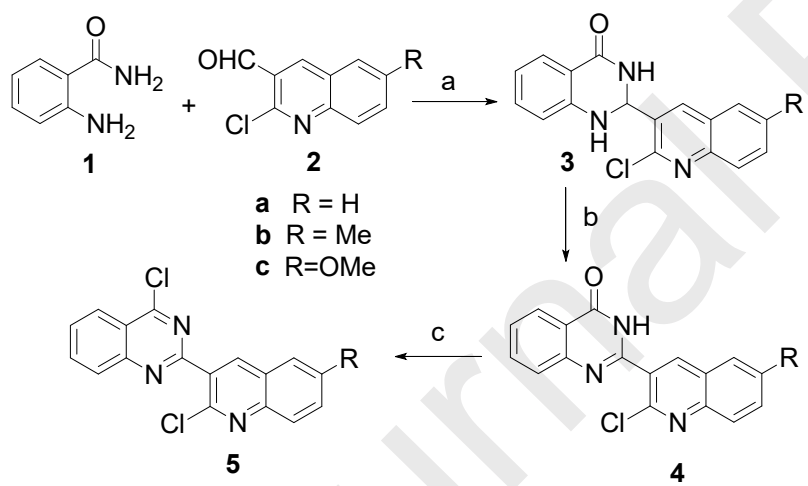

Scheme 1 Reagents and conditions: (a) $\mathrm{K}_{2} \mathrm{CO}_{3}$, DMF, $80^{\circ} \mathrm{C}$, 3h, 3a (94\%), 3b (91\%) 3c (90\%); (b) $\mathrm{I}_{2}$, DMF, $80^{\circ} \mathrm{C}, 6 \mathrm{~h}, \mathbf{4 a}(76 \%)$, 4b (84\%), 4c (86\%); (c) $\mathrm{POCl}_{3}$, reflux, $18 \mathrm{~h}, \mathbf{5 a}(76 \%), 5 \mathrm{~b}(78 \%), \mathbf{5 c}(70 \%)$.

Based on our previous study related to the synthesis of 4anilinoquinolino-quinazoline hybrids using $\mathrm{S}_{\mathrm{N}} \mathrm{Ar}$ reactions with various aromatic amines, ${ }^{8 c}$ we then decided to use phenols as nucleophiles. With 1 equiv. under refluxed acetonitrile in the presence of $\mathrm{K}_{2} \mathrm{CO}_{3}$, the corresponding adducts $\mathbf{6 a - h}$ were isolated in high yields (Table 1). A complete conversion occurred within a short time $(2 \mathrm{~h})$ with no substitution at the C-2 position of the quinoline. This high regioselectivity at the $\mathrm{C}-4$ position was confirmed by X-ray diffraction of $\mathbf{6 b}$ that reveals a dihedral angle of $50^{\circ}$ between the quinazoline and the quinoline subunits. ${ }^{10}$ Similarly, the 4-phenylthio derivative 6i was synthesized from thiophenol and $\mathbf{5 a}$ in $83 \%$ isolated yield.

On the other hand, when the reaction of $\mathbf{5 a}$ was performed with two equivalents of phenol under the same conditions, the formation of disubstituted quinazoline derivatives did not occur at all even after $16 \mathrm{~h}$ in $\mathrm{CH}_{3} \mathrm{CN}$ under reflux. However, modest yields of 7 a-d (23 to $53 \%$ ) were obtained by performing the reactions in refluxing DMF within $16 \mathrm{~h}$ (Table 2).

Table 1

Synthesis of 2-chloro-3-(4-aryloxyquinazol-2-yl)-quinolines 6

$\begin{array}{llll} & & \\ & & & \\ 6\end{array}$

To extend the range of available compounds, the reactions between compounds $\mathbf{6}$ and $p$-toluidine, selected as model aniline, were also examined. Aminoquinolines 8a-c were then prepared in good yields after one hour in refluxed $i$-PrOH in the presence of $1 \mathrm{~N} \mathrm{HCl}$ (Table 3). NMR and mass spectra of $\mathbf{6 a - i}, 7 \mathbf{a}-\mathbf{c}$ and 8a-c are in full agreement with the proposed structures. It is worthy to note the downfield shift of the NH signal in the ${ }^{1} \mathrm{H}$ NMR spectra of compounds 8 which would indicate that $\mathrm{NH}$ is located in an aromatic deshielding area of the twisted structure.

Table 2

Synthesis of 2-aryloxy-3-(4-aryloxyquinazol-2-yl)-quinolines 7

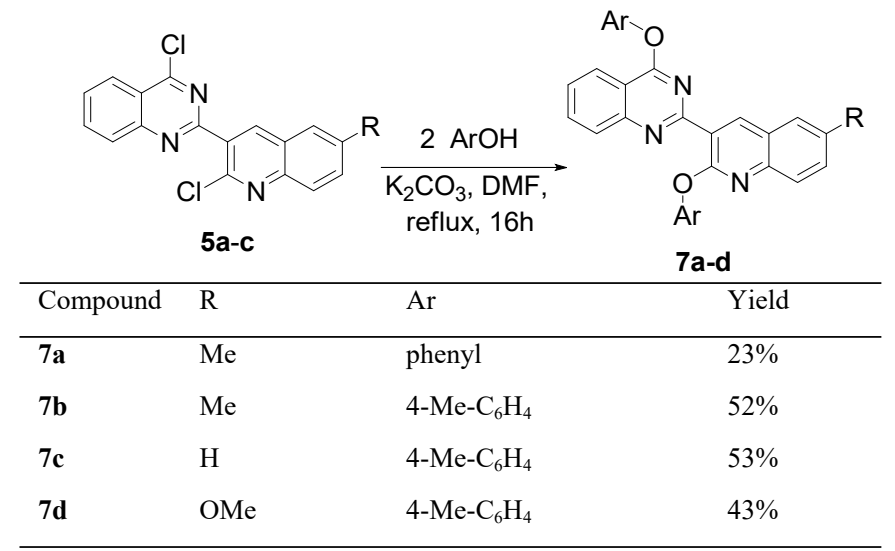

We then turned our attention to the formation of a new carbon-carbon bond. Introduction of an aryl or heteroaryl moiety at $\mathrm{C}-2$ of quinoline ring or C-4 of quinazoline was frequently carried out via Ni-catalyzed reaction of quinolone with arylzinc, ${ }^{11}$ 
Suzuki coupling with arylboronic acids $11 \mathrm{~b}$ or reacion quinoline $N$-oxide with indole. ${ }^{12}$

Table 3

Synthesis of 2-arylamino-3-(4-aryloxyquinazol-2-yl)-quinolines 8

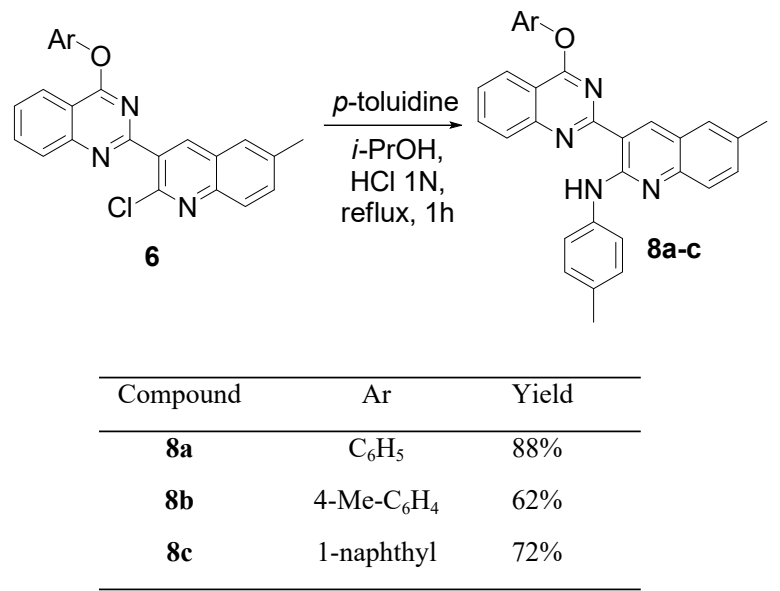

Despite the merit of these protocols, they are not free from limitations in terms of longer reaction time, use of costly catalysts, requirement of stringent conditions or multistep synthesis of starting materials. Over the last few years, the $\mathrm{C}-\mathrm{C}$ bond forming reactions between heteroaryl chlorides containing a $\mathrm{C}(\mathrm{Cl})=\mathrm{N}$ moiety and various electron rich arenes or heteroarenes in the presence of $\mathrm{AlCl}_{3}$ have been reported on several occasions. ${ }^{13}$ 2-Chloro-3-(4-(het)arylquinazol-2-yl)-quinolines 9ac were effectively obtained under this catalytic conditions in excellent yields from 2,4,6-trimethoxybenzene, indole and pyrrole (Scheme 2). Notably, as previously observed for $\mathrm{S}_{\mathrm{N}} \mathrm{Ar}$ reactions, no 2-substituted quinoline adducts were detected. In view of the mechanism generally proposed for this reaction, ${ }^{13 \mathrm{~g}}$ this regioselectivity could be explained by the favored complexation of $\mathrm{AlCl}_{3}$ to the quinazoline nitrogen. However, the use of an excess of 2,4,6-trimethoxybenzene with $\mathbf{5 b}$ as substrate, for $15 \mathrm{~h}$ instead of $3 \mathrm{~h}$, afforded the desired bi-substituted derivative $\mathbf{1 0 .}$

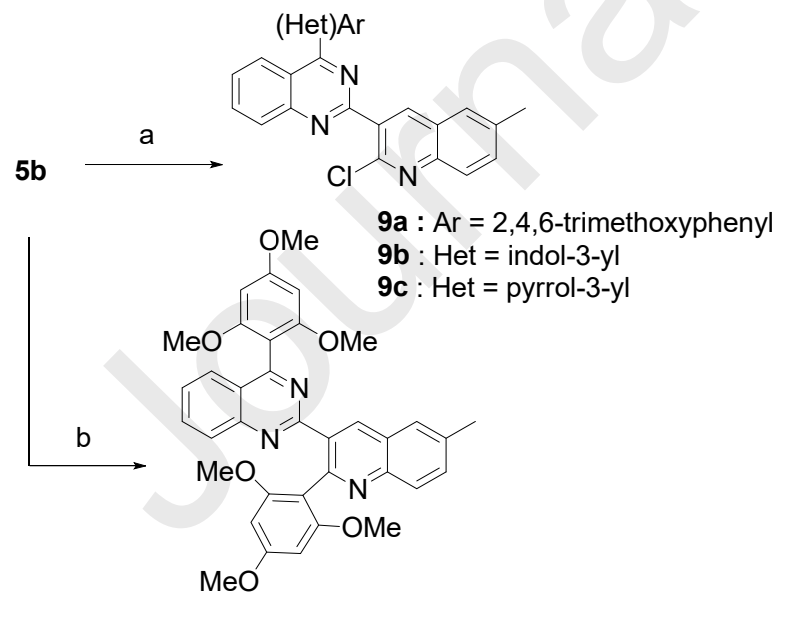

10

Scheme 2 Reagents and conditions: (a) (Het) $\mathrm{ArH}, \mathrm{AlCl}_{3}, \mathrm{DCE}, 80^{\circ} \mathrm{C}, 3 \mathrm{~h}, 9 \mathrm{9a}$ $(83 \%), 9 b(71 \%), 9 c(91 \%)$; (b) 1,3,5-trimethoxybenzene, $\mathrm{AlCl}_{3}, \mathrm{DCE}, 80^{\circ} \mathrm{C}$, $15 \mathrm{~h}, \mathbf{1 0}(61 \%)$

Finally, because morpholines are privileged substitiuents abundantly used as in drugs and medicinal chemistry, ${ }^{14}$ we applied the above-described methodologies to the synthesis of new derivatives presenting a morpholino substituent on the quinazoline or (and) quinoline parts. For example, in the presence of $\mathrm{iw}^{\prime}(\mathrm{c})$ eqiavalents of morpholine, the conversion of $\mathbf{5 b}$ to $\mathbf{1 1}$ was completed in methylene chloride at $45^{\circ} \mathrm{C}$ within $2 \mathrm{~h}$. With morpholine as solvent, at $80{ }^{\circ} \mathrm{C}$ for $1 \mathrm{~h}, \mathbf{1 2 b}$ and $\mathbf{1 2 c}$ were obtained in 88 and $84 \%$ yields, respectively (Scheme 3). Under the same conditions, were synthesized 13-15 with 2,4,6trimethoxyphenyl, indolyl and pyrrolyl moieties at the 4-position of quinazolines.

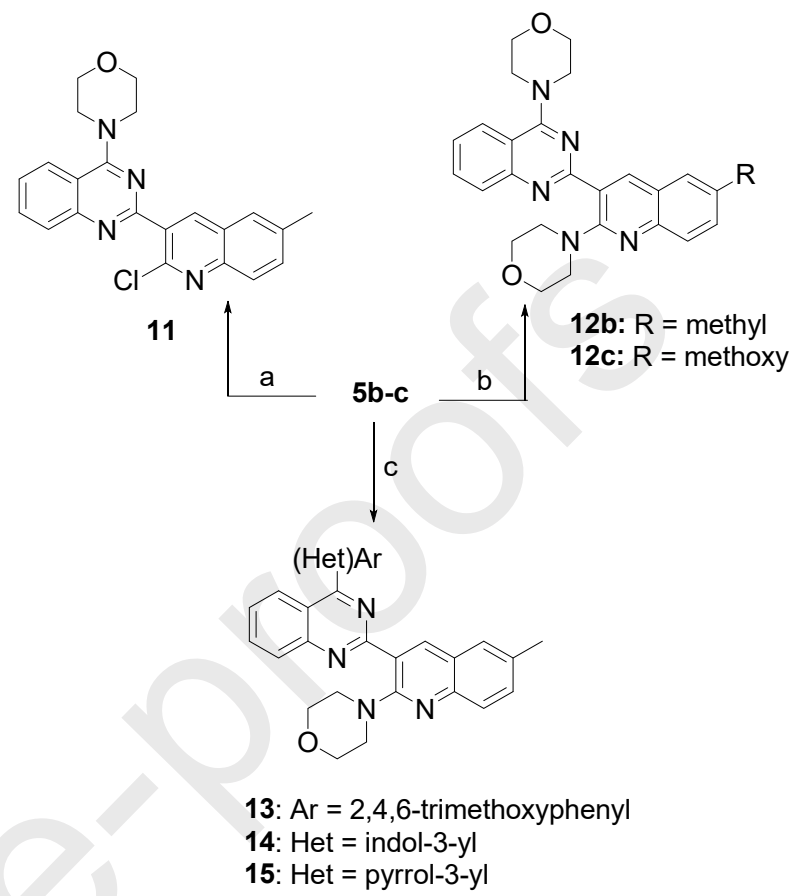

Scheme 3 Reagents and conditions: (a) morpholine (2 equiv), $\mathrm{CH}_{2} \mathrm{Cl}_{2}, 45^{\circ} \mathrm{C}$, 2h, 11 (91\%); (b) morpholine (solvent), $80^{\circ} \mathrm{C}, 1 \mathrm{~h}, \mathbf{1 2 b}(\mathrm{R}=\mathrm{Me}, 88 \%), 12 \mathrm{c}(\mathrm{R}$ $=\mathrm{OMe}, 84 \%)$; (c) (Het) $\mathrm{ArH}, \mathrm{AlCl}_{3}, 80^{\circ} \mathrm{C},\left(\mathrm{CH}_{2} \mathrm{Cl}\right)_{2}$, 3h, then morpholine $(2$ equiv), $\mathrm{CH}_{2} \mathrm{Cl}_{2}, 45^{\circ} \mathrm{C}, 2 \mathrm{~h}, 13(\mathrm{Ar}=2,4,6$-trimethoxyphenyl, 92\%), 14 (Het = indol-3-yl 78\%), 15 (Het = pyrrol-3-yl, 79\%).

Having in hands a small library of 3-(quinazol-2-yl)quinolines 6-15, we evaluated their biological activities as inhibitors of the purified human constitutive $20 \mathrm{~S}$ proteasome. The ability to inhibit the three proteolytic activities, ChT-L, T-L and PA, was measured by fluorescence. Owing to their weak (7c, 9a, 9b, 9c, 13) or moderate fluorescence (7d) at the working wavelengths, these compounds were excluded from the screening.

Ten compounds over 18 inhibited fairly (20\%) to strongly (90\%) the ChT-L or the PA activities at $50 \mu \mathrm{M}$ (Fig.3 A.). The T$\mathrm{L}$ activity was fairly inhibited by 4 products. Compounds that gave more than $70 \%$ inhibition were further characterized by their effect-dose response (Fig. S1 in supplementary material) to determine concentrations giving $50 \%$ inhibition $\left(\mathrm{IC}_{50}\right.$, table 4 ). As for the quinoline $20 \mathrm{~S}$ proteasome inhibitors saquinavir, ${ }^{3 \mathrm{~b}} \mathbf{5}$ $\mathbf{A H Q}^{3 \mathrm{ff}}$ and III $^{3 \mathrm{j}}$ (Fig. 1), the best compound 6e inhibits both ChT-L and PA activities, with a similar potency for PA and a lower one for ChT-L.

Table 4

$\mathrm{IC}_{50}(\mu \mathrm{M})$ values for inhibition of human constitutive $\mathrm{CP}\left(\mathrm{pH} 8,37^{\circ} \mathrm{C}\right)$

\begin{tabular}{lccccc}
\hline & $\mathbf{6 e}$ & $\mathbf{6 f}$ & $\mathbf{1 1}$ & $\mathbf{1 2 b}$ & chloroquine \\
\hline ChT-L activity & $35.4 \pm 0.6$ & $19 \pm 1$ & $44 \pm 1$ & $41 \pm 1$ & $6.3 \pm 0.4$ \\
PA activity & $13.2 \pm 0.6$ & $66 \% \mathrm{o}^{\mathrm{a}}$ & $55 \%^{\mathrm{a}}$ & $34.2 \pm 0.8$ & $22.5 \pm 0.6$ \\
\hline
\end{tabular}

a $\%$ inhibition at $50 \mu \mathrm{M}$ 
We also investigated the mechanism of inhilbiicu by compound 6e (Fig. S2 and Fig. S3 in supplementary material). ${ }^{15}$ A competitive inhibition of the ChT-L activity was observed..$^{15}$ This indicates that inhibitor $\mathbf{6 e}$ binds exclusively to the free enzyme with an inhibition constant $\mathrm{Ki}=19 \pm 1 \mu \mathrm{M}$. Such a competitive inhibition mechanism has been reported mainly for the ChT-L activity of non-covalent peptide derivatives ${ }^{16}$ and also for the PA activity of tamoxifen derivatives. ${ }^{17}$ The PA activity was inhibited non-competitively. ${ }^{15}$ Inhibitor $6 \mathrm{e}$ binds with an equal affinity to the enzyme alone or the enzyme in complex with the substrate $\left(\mathrm{K}_{i}=\mathrm{K}_{i}^{\prime}=13.2 \pm 0.6 \mu \mathrm{M}\right)$. Non-competitive inhibition of $20 \mathrm{~S}$ proteasome has been observed for the PA activity of quinoline 5-AHQ (Fig.1), ${ }^{3 \mathrm{f}}$ and for the ChT-L activity of oxadiazoles, $^{9 \mathrm{a}}$ tamoxifen derivatives $^{17}$ or peptide derivatives. ${ }^{16 a, 18}$

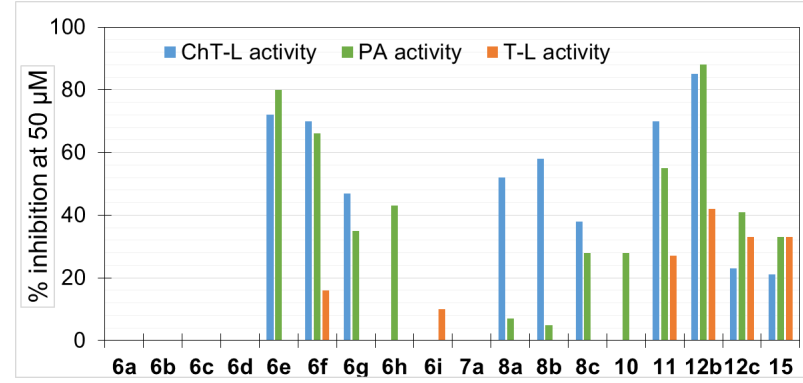

Fig.3 Effect of 3-(quinazol-2-yl)-quinolines 6-15 on human constitutive $\mathrm{CP}$ $\left(\mathrm{pH} 8,37^{\circ} \mathrm{C}\right)$. Compared inhibitions of the ChT-L, PA and T-L activities by compounds 6-15 at $50 \mu \mathrm{M}$.

The many crystallographic structures of inhibitors in complex with 20 S proteasome have provided a deep understanding of the binding channel and specificity pockets that can be targeted by competitive inhibitors. ${ }^{19}$ However a non-competitive modulation of $20 \mathrm{~S}$ proteasome suggests that binding to other sites could occur while blocking $20 \mathrm{~S}$ proteasome activities. As yet, the only direct evidences $\left(\mathrm{NMR}^{3 \mathrm{e}}\right.$ or $\left.\mathrm{X}-\mathrm{ray}^{20}\right)$ for such a mechanism involving non-peptide derivatives have been brought using quinoline derivatives (respectively chloroquine or I)

We described in this paper an efficient synthesis of polysubstituted 3-(quinazol-2-yl)-quinoline derivatives 6-15 in few steps and high yields. Chemical diversity was introduced by selective mono or double $\mathrm{S}_{\mathrm{N}} \mathrm{Ar}$ of a range of phenols, thiophenol, amines or anilines with the easily prepared di-chloro derivatives 5. Aryl or heteroaryl carbon nucleophiles allowed the $\mathrm{AlCl}_{3}$ mediated and controlled creation of one or two C-C bonds.

Several 3-(quinazol-2-yl)-quinoline derivatives inhibited the ChT-L and PA activities of the human constitutive 20S proteasome. The best compound $\mathbf{6 e}$ inhibited these activities by different mechanisms, with moderate affinities $(\mathrm{Ki}=13-19 \mu \mathrm{M})$.

\section{Acknowledgments}

This work was supported by the University of Rennes 1 and the Centre National de la Recherche Scientifique (CNRS). IB gratefully acknowledges le Ministère de l'Enseignement Supérieur et de la Recherche Scientifique (Algeria) and The Algerian-French scholarship program PROFAS B+.

\section{Supplementary Material}

Supplementary data to this article can be found online at
Roferzules and notes

[1] (a) Solomon, V. R.; Lee, H. Curr. Med. Chem. 2011, 18, 1488-1508;

(b) Musiol, R. Expert Opin. Drug Discov. 2017, 12, 583597.

[2] (a) Manasanch, E. E.; Orlowski, R. Z. Nat. Rev. Clin. Oncol. 2017, 14, 417;

(b) Park, J. E.; Miller, Z.; Jun, Y.; Lee, W.; Kim, K. B. Translational Research 2018, 198, 1-16.

[3] (a) Perez, C.; Li, J.; Parlati, F.; Rouffet, M.; Ma, Y.; Mackinnon, A. L.; Chou, T.-F.; Deshaies, R. J.; Cohen, S. M. J. Med. Chem. 2017, 60, 1343-1361;

(b) Pajonk, F.; Himmelsbach, J.; Riess, K.; Sommer, A.; McBride, W. H. Cancer Res. 2002, 62, 5230-5235;

(c) Mao, X.; Li, X.; Sprangers, R.; Wang, X.; Venugopal, A.; Wood, T.; Zhang, Y.; Kuntz, D. A.; Coe, E.; Trudel, S.; Rose, D.; Batey, R. A.; Kay, L. E.; Schimmer, A. D. Leukemia 2009, 23, 585-590;

(d) Zhai, S.; Yang, L.; Cui, Q. C.; Sun, Y.; Dou, Q. P.; Yan, B. JBIC, J. Biol. Inorg. Chem. 2010, 15, 259-269;

(e) Ruschak, A. M.; Kay, L. E. Proc. Natl. Acad. Sci. U. S. A. 2012, 109, E3454-E3462, SE3454/1-SE3454/31;

(f) Li, X.; Wood, T. E.; Sprangers, R.; Jansen, G.; Franke, N. E.; Mao, X.; Wang, X.; Zhang, Y.; Verbrugge, S. E.; Adomat, H.; Li, Z. H.; Trudel, S.; Chen, C.; Religa, T. L.; Jamal, N.; Messner, H.; Cloos, J.; Rose, D. R.; Navon, A.; Guns, E.; Batey, R. A.; Kay, L. E.; Schimmer, A. D. J. Natl. Cancer Inst. 2010, 102, 1069-1082;

(g) Pundir, S.; Vu, H.-Y.; Solomon, V. R.; McClure, R.; Lee, H. Cancer Research 2015, 75, 4164-4175;

(h) Basse, N.; Montes, M.; Marechal, X.; Qin, L.; BouvierDurand, M.; Genin, E.; Vidal, J.; Villoutreix, B. O.; Reboud-Ravaux, M. J. Med. Chem. 2010, 53, 509-513;

(i) Di Giovanni, C.; Ettari, R.; Sarno, S.; Rotondo, A.; Bitto, A.; Squadrito, F.; Altavilla, D.; Schirmeister, T.; Novellino, E.; Grasso, S.; Zappala, M.; Lavecchia, A. Eur. J. Med. Chem. 2016, 121, 578-591;

(j) McDaniel, T. J.; Lansdell, T. A.; Dissanayake, A. A.; Azevedo, L. M.; Claes, J.; Odom, A. L.; Tepe, J. J. Bioorg. Med. Chem. 2016, 24, 2441-2450.

[4] Alagarsamy, V.; Chitra, K.; Saravanan, G.; Solomon, V. R.; Sulthana, M. T.; Narendhar, B. Eur. J. Med. Chem. 2018, $151,628-685$.

[5] Chen, J.; Natte, K.; Neumann, H.; Wu, X.-F. RSC $A d v$. 2014, 4, 56502-56505.

[6] Sutherland, H. S.; Hwang, I. Y.; Marshall, E. S.; Lindsay, B. S.; Denny, W. A.; Gilchrist, C.; Joseph, W. R.; Greenhalgh, D.; Richardson, E.; Kestell, P.; Ding, A.; Baguley, B. C. Invest New Drugs 2012, 30, 2035-45.

[7] Derabli, C.; Boulcina, R.; Kirsch, G.; Carboni, B.; Debache, A. Tetrahedron Lett. 2014, 55, 200-204.

[8] (a) Mahdjoub, S.; Boulcina, R.; Yildirim, M.; Lakehal, S.; Boulebd, H.; Debache, A. Synth. Commun. 2018, 48, 23662381;

(b) Derabli, C.; Boualia, I.; Abdelwahab, A. B.; Boulcina, R.; Bensouici, C.; Kirsch, G.; Debache, A. Bioorg. Med. Chem. Lett. 2018, 28, 2481-2484;

(c) Derabli, C.; Boulcina, R.; Kirsch, G.; Debache, A. Tetrahedron 2017, 73, 351-358.

[9] (a) Maréchal, X.; Genin, E.; Qin, L.; Sperandio, O.; Montes, M.; Basse, N.; Richy, N.; Miteva, M. A.; Reboud-Ravaux, M.; Vidal, J.; Villoutreix, B. O. Curr. Med. Chem. 2013, 20, 2351-2362;

(b) Villoutreix, B. O.; Khatib, A. M.; Cheng, Y.; Miteva, M. A.; Marechal, X.; Vidal, J.; Reboud-Ravaux, M. Oncotarget 2017, $8,10437-10449$.

[10] CCDC 1871916 contains the crystallographic data for compounds $6 \mathbf{b}$. These data can be obtained free of charge 
from The Cambridge Crystallographic Data C.ntiv via www.ccdc.cam.ac. uk/data_request/cif.

[11] (a) Tobisu, M.; Hyodo, I.; Chatani, N. J. Am. Chem. Soc. 2009, 131, 12070-12071;

(b) Fleckenstein, C. A.; Plenio, H. Chem. Eur. J. 2008, 14 4267-4279.

[12] Hoemann, M. Z.; Kumaravel, G.; Xie, R. L.; Rossi, R. F.; Meyer, S.; Sidhu, A.; Cuny, G. D.; Hauske, J. R. Bioorg; Med. Chem. Lett. 2000, 10, 2675-2678.

[13] (a) Pal, M.; Batchu, V. R.; Parasuraman, K.; Yeleswarapu, K. R. J. Org. Chem. 2003, 68, 6806-6809;

(b) Pal, M.; Batchu, V. R.; Dager, I.; Swamy, N. K.; Padakanti, S. J. Org. Chem. 2005, 70, 2376-2379;

(c) Kodimuthali, A.; T. C, N.; Prasunamba, P. L.; Pal, M. Tetrahedron Lett. 2009, 50, 354-358;

(d) Kodimuthali, A.; Chary, B. C.; Prasunamba, P. L.; Pal, M. Tetrahedron Lett. 2009, 50, 1618-1621;

(e) Kumar, K. S.; Chamakuri, S.; Vishweshwar, P.; Iqbal, J.; Pal, M. Tetrahedron Lett. 2010, 51, 3269-3273;

(f) Rajasekhar, M.; Rao, K. U. M.; Sundar, C. S.; Reddy, N. B.; Kumar Nayak, S. K.; Reddy, C. S. Chem. Pharm. Bull 2012, 60, 854;

(g) Sunke, R.; Nallapati, S. B.; Kumar, J. S.; Shiva Kumar, K.; Pal, M. Org. Biomol. Chem. 2017, 15, 4042-4057.

[14] (a) Taylor, R. D.; MacCoss, M.; Lawson, A. D. G. J. Med. Chem. 2014, 57, 5845-5859;

(b) Vitaku, E.; Smith, D. T.; Njardarson, J. T. J. Med. Chem. 2014, 57, 10257-10274;

(c) Ritchie, T. J.; Macdonald, S. J. F.; Peace, S.; Pickett, S. D.; Luscombe, C. N. MedChem Comm 2012, 3, 1062-1069.

[15] Bisswanger, H.; Wiley-VCH Verlag GmbH \& Co: Weinheim, 2008.

[16] (a) Desvergne, A.; Genin, E.; Maréchal, X.; Gallastegui, N.; Dufau, L.; Richy, N.; Groll, M.; Vidal, J.; ReboudRavaux, M. J. Med. Chem. 2013, 56, 3367-3378;

(b) Maréchal, X.; Pujol, A.; Richy, N.; Genin, E.; Basse, N.; Reboud-Ravaux, M.; Vidal, J. Eur. J. Med. Chem. 2012, 52 , 322-7;

(c) Koguchi, Y.; Kohno, J.; Nishio, M.; Takahashi, K.; Okuda, T.; Ohnuki, T.; Komatsubara, S. J. Antibiot. 2000, $53,105-9$.

[17] Hasegawa, M.; Yasuda, Y.; Tanaka, M.; Nakata, K.; Umeda, E.; Wang, Y.; Watanabe, C.; Uetake, S.; Kunoh, T.; Shionyu, M.; Sasaki, R.; Shiina, I.; Mizukami, T. Eur. J. Med. Chem. 2014, 71, 290-305.

[18] (a) Myung, J.; Kim, K. B.; Lindsten, K.; Dantuma, N. P.; Crews, C. M. Mol. Cell 2001, 7, 411-420;

(b) Santos, R. d. L. A.; Bai, L.; Singh, P. K.; Murakami, N.; Fan, H.; Zhan, W.; Zhu, Y.; Jiang, X.; Zhang, K.; Assker, J. P.; Nathan, C. F.; Li, H.; Azzi, J.; Lin, G. Nat. Commun. 2017, 8, 1692;

(c) Karpowicz, P.; Osmulski, P. A.; Witkowska, J.; Sikorska, E.; Gizynska, M.; Belczyk-Ciesielska, A.; Gaczynska, M. E.; Jankowska, E. PLoS One 2015, 10, e0143038.

[19] Borissenko, L.; Groll, M. Chem. Rev. 2007, 107, 687-717.
[2.0] Beck, P.; Reboud-Ravaux, M.; Groll, M. Angew. Chem. Int. Ed. 2015, 54, 11275-11278.

\section{Graphical Abstract}

\section{Highlights:}

- A new series of polysubstituted 3-(quinazol2-yl)-quinolines have been synthesized by SNAr reaction.

- Various amines, phenols and thiophenol have been used as reactants.

- $\mathrm{AlCl}_{3}$ has mediated $\mathrm{C}-\mathrm{C}$ bond forming reactions

- The methodology can be viewed as a useful alternative to the Suzuki reactions.

- Some of the synthesized 3-(quinazol-2-yl)quinolines inhibit the human $20 \mathrm{~S}$ proteasome.

\section{Declaration of interests}

The authors declare that they have no known competing financial interests or personal relationships that could have appeared to influence the work reported in this paper.

$\square$ The authors declare the following financial interests/personal relationships which may be considered as potential competing interests:

Synthesis of novel 3-(quinazol-2-yl)-quinolines via $S_{N} A r$ and aluminum chloride-induced (hetero) arylation reactions and biological evaluation as proteasome inhibitors

Imen Boualia, Abdelmadjid Debache, Raouf Boulcina,* Thierry Roisnel, Fabienne Berrée, Joelle Vidal, ${ }^{*}$ and Bertrand Carboni

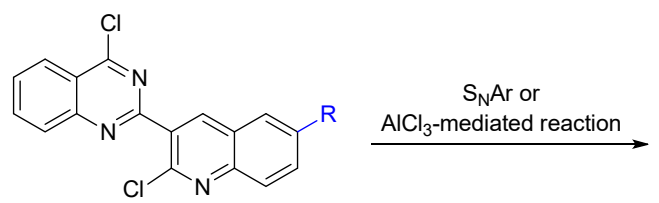

$\mathrm{R}=\mathrm{H}, \mathrm{Me}, \mathrm{OMe}$

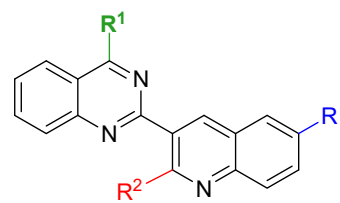

$\mathrm{R}^{1}=\mathrm{OAr}$, SPh, HetAr, morpholino $\mathrm{R}^{2}=\mathrm{Cl}, \mathrm{OAr}$, NHTol, HetAr, morpholino 26 examples

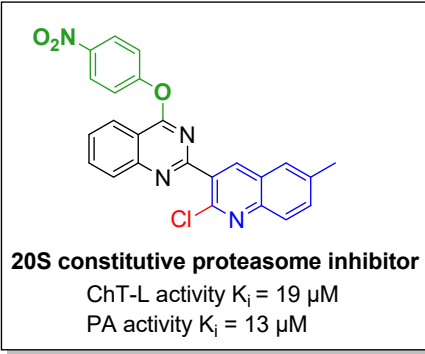

